\title{
Probiotics and Relationship Between Probiotics and Cancer Types
}

\section{Probiyotikler ve Probiyotiklerin Kanser Türleriyle İlişkisi}

\author{
(1) Dilruba ŞENER, id Hafsa Nur BULUT, id Ayşe GÜNEŞ BAYIR
}

Bezmialem Vakıf University Faculty of Medicine, Department of Nutrition and Dietetics, İstanbul, Turkey

\begin{abstract}
Cancer is a disease with a high mortality rate worldwide. Moreover, this rate is increasing day by day. It is expected to rise to first place by 2030 , leaving cardiovascular diseases behind, which is the most common cause of death in the world. Today, it is known that cancer is the second most common cause of death. The process of cancer and its treatment reducethe quality of life. To improve this process, the effects of probiotics on some types of cancer, especially colorectal cancer, are examined in studies conducted today. Studies are showing that probiotics provide positive results in cancer prevention and treatment. However, some studies argue that they should not be used, putting forward the fact they may cause infection in patients with very weak immunity. The mechanisms for the antitumor properties of probiotics have not been fully explained yet. It is associated with some pathways which mainly focus on the gut microbiota. The opinion that the effects of probiotics on cancer are dependent on dose, strain, and species is accepted as a general conclusion. Besides, probiotics must be consumed regularly and the consumed product must contain the minimum number of microorganisms (approximately $100 \mathrm{~g} /$ day) to provide the intended effect. In this review, the effects of probiotics, of which positive and negative effects on individuals with cancer are still being discussed, on different types of cancer are presented in the light of current literature.
\end{abstract}

Keywords: Probiotics, cancer, cancer types

\section{ÖZ}

Kanser, dünya genelinde ölüm oranı oldukça yüksek olan bir hastalıktır. Üstelik bu oran her geçen gün yükselmektedir. Öyle ki, 2030 yılına kadar dünyada görülen en yaygın ölüm nedeni olan kardiyovasküler hastalıkları geride bırakarak birinci sıraya yükselmesi beklenmektedir. Günümüzde kanserin ikinci en yaygın ölüm nedeni olduğu bilinmektedir. Kanser süreci ve tedavisi hayat kalitesini düşürmektedir. Bu süreci iyileştirmek adına, günümüzde yapılan çalışmalarda, kolorektal kanser başta olmak üzere bazı kanser türlerinde probiyotiklerin etkisi incelenmektedir. Probiyotiklerin kanseri önlemede ve kanser tedavisinde olumlu sonuçlar verdiğine dair çalışmalar bulunmaktadır. Ancak, bağışıklığı çok zayıf olan hastalarda infeksiyona neden olabileceği gibi sebepler öne sürülerek kullanılmaması gerektiğini savunan çalışmalar da mevcuttur. Probiyotiklerin antitümör özelliklerine dair mekanizmalar, henüz tam anlamıla açıklanamamıştır. Merkezinde barsak mikrobiyotasının bulunduğu bazı yolaklarla ilişkilendirilmektedir. Probiyotiklerin kanser üzerine olan etkilerinin doza, suşa ve türe bağlı olduğu görüşü, genel bir sonuç olarak kabul edilmektedir. Ayrıca, probiyotiklerin istenilen etkiyi sağlayabilmeleri için düzenli bir şekilde tüketilmesi ve tüketilen ürünün minimum mikroorganizma sayısını (yaklaşık olarak $100 \mathrm{~g} /$ gün) içermesi gerekmektedir. Bu derlemede, kanserli bireyler üzerindeki olumlu ve olumsuz etkileri hala tartışılmakta olan probiyotiklerin farklı kanser türleri üzerine etkileri güncel literatür ışığında sunulmaktır.

Anahtar Sözcïkler: Probiyotikler, kanser, kanser türleri

Address for Correspondence: Ayşe GÜNEŞ BAYIR, Bezmialem Vakıf University Faculty of Medicine, Department of Nutrition and Dietetics, İstanbul, Turkey

E-mail: agunes@bezmialem.edu.tr ORCID ID: orcid.org/0000-0002-9993-7850 


\section{Introduction}

The concept of probiotic, which means "for life" in Greek, is used to describe living microorganisms that do not have diseasecausing effects and their effects on hosts (1). According to the international FAO/WHO definition, probiotics are defined as "live microorganisms that provide health benefits to the host when administered in adequate amounts" (2). Thanks to their metabolic activities, probiotic microorganisms play an important role in the use of nutrients in the body. Moreover, probiotics greatly affect the development and performance of the immune system and other functions. In the production of probiotic foods, Lactobacillus and Bifidobacterium species are often preferred among probiotic bacteria (3). Enterococcus, Streptococcus and Leuconostoc bacteria are rarely used in probiotic food production.

Probiotic products may contain one or more strains (1). The benefits of a probiotic formulation also differ according to the patient group. Limited studies have shown greater efficacy when multiethnic probiotics are used. Probiotics exert their benefits in a variety of ways, such as lowering the intestinal $\mathrm{pH}$, reducing the colonization of pathogenic microorganisms, and altering the host immune response (4). In order for probiotics to provide targeted health benefits, probiotic foods must contain the minimum number of viable microorganisms required during consumption (5).

According to the oldest known records, cancer is a serious health problem that has been seen since 3,000 BC and its incidence continues to increase even today (6). Cancer is a difficult disease to fight because of the many physical, social, material and spiritual ailments it carries with it. Approximately one million patients are newly diagnosed as having cancer in the world every year (7). Cancer, a disease characterized by uncontrolled proliferation in cells, causes millions of deaths every year and is seen as one of the biggest health problems that humanity struggles with (8). For this reason, a wide variety of methods are being tried to be produced by countless scientists for the treatment of cancer today.

Studies on the inclusion of probiotics among the adjunct applications to traditional cancer treatments have increased significantly in recent years (9). Probiotics exert their cancerpreventing and therapeutic effects mainly by regulating the intestinal microbiota, improving the physico-chemical conditions of the colon, increasing the intestinal barrier function, modulating intestinal bacterial metabolism and enzymes, thus preventing carcinogenics, secreting anticancer metabolites and reducing inflammation $(10,11)$. More studies are needed to determine how and to what extent the positive effects of probiotics affect the cancer rate (12).

\section{Probiotics}

In the human gut, the microbiota interacts intensely with nutrients and host cells. This process is a complex biosystem that is important for intestinal homeostasis and helps human development. The intestinal microbiota plays an important role in the use of nutrients in the body, thanks to its metabolic activities (2). Moreover, it greatly affects the development and performance of the immune system and other functions. The interaction between the gut microbiota and the host organism provides many benefits for both. The useful basic functions of the microbiota in the host organism are:

1- Participation in the formation of the intestinal wall

2- Providing resistance to colonization

3- Production of short chain fatty acids

4- Vitamin synthesis: Especially B group and K vitamins

5- Interacting with the mucosal immune system

6- Degradation of xenobiotics with genes capable of synthesizing enzymes with catabolic activity against these compounds.

Metabolism, barrier effect and trophic functions, which are the main functions of the microbiota, are accepted as active components of intestinal physiology (3). The bacterial imbalance that can cause various diseases that occur here is called dysbiosis. It is known that the microbiota changes positively with the intake of live bacteria (probiotics) or indigestible substrates (prebiotics) for the prevention and even treatment of some diseases. Today, it is accepted that the intestinal microbiota interacts with human health and is changed by probiotics.

According to the experts of the World Health Organization (WHO) and the Food and Agriculture Organization (FAO), a bacterial strain to be considered a probiotic; first of all, the species must reach the region of influence and withstand the physiological stress (acid, stomach and intestinal $\mathrm{pH}$ value and bile salts) to which it will be exposed in the body. Also, a probiotic must have proven beneficial effects for the host and must not pose any risk, and must preserve its properties during the production process and storage. Microorganisms used as probiotics can be obtained from different genera and species (13). Yeast (Saccharomyces cerevisiae) and bacteria; lactic acid bacteria (such as Lactobacillus, Streptococcus and Enterococcus species), Bifidobacterium, Propionibacterium, Bacillus and Escherichia coli species are used as probiotics. They can be natural (used in foods for everyone) or genetically modified for a specific effect. Among the probiotic strains, those belonging to the Enterococcus genus have a higher risk potential. Although rare, they can cause systemic infections and antibiotic resistance in the host. Probiotic products may contain one or more strains (1). The benefits of a probiotic formulation also differ according to the patient group. Limited studies have shown greater efficacy when multiethnic probiotics are used. The WHO and FAO have developed joint guidelines. FAO/WHO guidelines on probiotics are used as a global standard for the evaluation of probiotics in food. Required instructions for the directive are as follows:

1. Strain definition.

2. Functional characterization of strain(s) for safety and probiotic properties.

3. Confirmation of health benefits in human studies.

4. Honest, non-misleading efficacy claims and ingredient labeling for the entire shelf life. 
The main benefits of probiotics are: Protection against gastrointestinal pathogens, strengthening the immune system, lowering serum cholesterol and blood pressure, anti-carcinogenic activity, improving nutrient utilization and bioavailability (5). Probiotics exert their benefits in a variety of ways by lowering intestinal $\mathrm{pH}$, reducing colonization and invasion of pathogenic organisms, and altering the host immune response (4). In order for probiotics to provide the targeted health benefit, they must contain the minimum number of viable microorganisms required at the time of consumption (5). Generally, the minimum level recommended by the food industry is 106 c.f.u (colony forming unit) $/ \mathrm{mL}$. The FDA also supports this. Daily 108-109 c.f.u/mL probiotic is necessary to be effective in humans. In addition, probiotic foods should be consumed regularly in an amount of about $100 \mathrm{~g} /$ day to deliver approximately $10^{9}$ living cells to the intestines. In particular, probiotics involving the gastrointestinal tract appear to be effective in the prevention and treatment of various medical conditions. Studies supporting its effects in other conditions are often contradictory.

Probiotic bacteria belonging to the Lactobacillus and Bifidobacterium genera are considered part of the normal human microbiota (14). Lactobacillus and Bifidobacterium are generally considered safe. Some data suggest that probiotics may contribute to the strengthening of the intestinal mucosal barrier function, particularly by affecting intestinal epithelial cells and macrophages (2). The primary effect of probiotics is the barrier effect, which is related to the modulation of the host microbiota. It creates resistance to colonization by preventing or limiting colonization of pathogenic bacteria. This barrier effect can also act in different ways, such as inhibition of adhesion and competition for binding sites. Improving the barrier function of the intestinal mucosa is also a secondary mode of action of probiotics. This barrier function is related to the tightness of the connections between intestinal epithelial cells. It also produces mucus with antimicrobial peptides (defensins, lysozyme) and Paneth cells and mucus cells. Thus, it participates in the barrier function by acting as a protective layer that prevents direct contact of the intestinal lumen with bacteria. The third mode of action of probiotics is the modulation of the immune system. More than $70 \%$ of the immune cells make up the gut-associated lymphoid tissue, particularly in the small intestine. Among probiotic bacteria, especially lactic bacteria, have local or systemic effects depending on their cytokine profile. The mechanism of action of probiotics must be perfectly determined. The properties of the probiotic strain should not change during the production process and storage before use. It must not contain any diseasecausing factors.

Probiotics, especially Bifidobacterium and Lactobacillus, have a long history in terms of safety. In addition, these bacteria and especially Lactobacillus are frequently encountered in nature. Lactobacillus, Bifidobacteria, Lactococcus, and yeasts are generally in the category of "Generally recognised as safe" organisms. However, a few infections have been reported, mostly in immunocompromised patients. Not all probiotics used are included in this category. It must be scientifically proven whether probiotics are effective and safe (14). The probiotic effect of each strain is unique. Therefore, each strain of bacteria should be individually tested for its associated health benefit. Its efficacy has not been proven due to very low quality studies, microbiota variability and response to modulation attempts, and the diversity of probiotic strains used (3). It is necessary to be able to work on large cohorts to account for inter-patient variability. There should be a global approach to the microbiota. It is also important to select the correct probiotic strain for a particular application, because the effect of the probiotic is strain dependent. All these indicators pave the way for research focusing on the benefits of modulation and its relationship to the microbiota and host health.

There are several risk theories regarding the use of probiotics. It is thought that probiotics may cause infections due to translocation. Some strains appear to have the capacity to reduce or increase translocation of gut bacteria. Another negative effect of probiotics may be due to the production of metabolites with toxic potential. D-lactate production during bacterial fermentation, which is responsible for lactic acidosis, is one of the possible risks. In children with short bowel syndrome, administration of a microbiota abnormally rich in lactobacilli or the administration of probiotic Lactobacillus strains was associated with acidosis resulting in encephalopathy or hyperventilation. However; no complaint of lactic acidosis is reported in healthy children. One of the most important risks is the transfer of antibiotic resistance genes between the host's common bacteria and probiotic strains in the host digestive tract. Gene transfers may occur in the microbiota in the gut and the diversity of bacteria in this area may increase. Therefore, probiotic strains can be vectors of resistance genes that act as donors or recipients. It is recommended to use probiotic strains that do not contain acquired and potentially transferable resistance genes. This raises the problem of using probiotic strains belonging to the species that naturally carry virulence and/or resistance to antibiotics such as enterococci or E. coli. Genomic analyzes of probiotic enterococci strains proved that these strains lacked virulence factors.

\section{Prebiotics}

Prebiotics are fibers, which are generally indigestible food components, and they positively affect host health by stimulating the growth and/or activity of some microorganisms in the colon (1). FAO and WHO define prebiotics as food ingredients that confer health benefits on the host associated with modulation of microbiota. Prebiotics consist of various carbohydrate components that are not well understood according to their origin, fermentation profile and appropriate dosage for health effects. Some sources of prebiotics are; breast milk, soybeans, sources of inulin (such as jerusalem artichoke, chicory root, etc.), raw oats, unrefined wheat, unrefined barley, black cumin, non-digestible carbohydrates and especially non-digestible oligosaccharides.

\section{Synbiotics}

Gibson and Roberfroid, when introducing the concept of prebiotics, have stated that prebiotics have additional benefits 
when combined with probiotics to form what they call synbiotic (1). Synbiotics were developed to overcome possible survival challenges for probiotics. An improvement in the survival of probiotic bacteria in the passage through the upper intestinal tract was observed when synbiotics were used.

\section{Cancer}

According to the oldest known records, cancer is a serious health problem that has been seen since 3,000 $\mathrm{BC}$ and its incidence continues to increase even today (6). Cancer is a difficult disease to fight because of the many physical, social, material and spiritual ailments it carries with it. Approximately one million patients are newly diagnosed as having cancer in the world every year (7). Cancer formation is caused by the formation of abnormal cells (neoplasia) that can multiply uncontrollably in any part of the body. As these cells continue to multiply, they become a mass called a tumor. Although the formation of these neoplastic masses, which are independent of control mechanisms, can be dangerous, they are mostly harmless (8). As a matter of fact, in order to be able to talk about cancer, the features of invasion and metastasis along with uncontrolled proliferation must be present in the cell (7). When a normal cell acquires each of these malignant properties, it is considered to have passed into the next stage of carcinogenesis. These four stages are as follows: Stage 1 (initiation, progressing very slowly, also called latent stage), Stage 2 (promotion, much faster growing cell groups, promoters are effective), Stage 3 (progression, acting independently of the surrounding tissue, genetic mutations are now irreversible) and Stage 4 (invasion and metastasis, very difficult to heal) (8). Cancer development can be stopped by intervention in cells in the early stages of mutation. For this reason, diagnostic tests without risk factors are important for each individual. Especially people with a family history of cancer are expected to be more sensitive about routine controls (6). Despite the efforts to develop standard approaches for certain types of cancer, it is known that cancer is a disease specific to the individual. Chemotherapy, radiotherapy and surgical methods are frequently used in cancer treatment and constitute the most important parts of the treatment.

In summary, cancer, which is a disease characterized by uncontrolled proliferation in cells, causes millions of deaths every year and is one of the biggest health problems that humanity struggles with (7). For this reason, a wide variety of methods are being tried to be produced by countless scientists for the treatment of cancer today.

\section{Mechanism of Effect of Probiotics in Cancer}

Studies on the inclusion of probiotics among the adjunct applications to traditional cancer treatments have increased significantly in recent years (9). However, the mechanisms related to the antitumor properties of probiotics are still not fully elucidated and remain partially unclear. The gut microbiota is associated with a number of pathways that are considered to play a central role in this process. Some of these pathways are (7);

1. Regulating the microbiota by inhibiting pathogens that produce cancer-promoting agents
2. Inhibition of pathogenic microorganisms and activation of immunomodulatory cells by production of antimicrobial substances

\section{Reduction of DNA damage and genotoxicity}

\section{Production of anti-cancer metabolites}

Probiotics exert their cancer-preventing and therapeutic effects mainly by regulating the intestinal microbiota, improving the physico-chemical conditions of the colon, increasing the intestinal barrier function, modulating intestinal bacterial metabolism and enzymes, thus preventing carcinogens, secreting anticancer metabolites, and reducing inflammation $\left(10,11^{\text {th }}\right.$. More studies are needed to determine how and to what extent the positive effects of probiotics affect the cancer rate (12).

\section{The Relationship of Probiotics with Some Kinds of Cancer Cancers of the Gastrointestinal System}

Of all cancers in the World, 25\% are cancers of the digestive system. Of cancer-related deaths, $9 \%$ are due to gastrointestinal (GI) cancer types (15). GI cancers are defined as multifactorial diseases and are associated with complex pathways such as genetics, epigenetics, immunity, environmental factors, diet and vital changes, which have a known effect on the gut microbiota. Studies show that probiotics have positive effects on GI cancers. Important studies have shown that probiotics have antiproliferative or pro-apoptotic activities (16). Colon cancer and stomach cancer are the most commonly studied cancers among GI cancers. Although lactic acid bacteria and Bifidobacterium are frequently used among probiotics, Streptococcus thermophilus, Enterococcus, Escherichia coli and Saccharomyces boulardii species are also included in the studies $(16,17)$. Recent studies have shown the anti-proliferative role of L. rhamnosus GG strain in human gastric cancer (GC) and colon cancer cells (18). Another probiotic product, Bifidobacterium adolescentis SPM0212, inhibits the proliferation of colon cancer cell lines including HT29, SW 480 and Caco-2 (17). With this; Bacillus polyfermenticus, L. acidophilus 606, $L G G / B b 12$ and $L G G /$ Bifidobacterium animalis subsp. lactis is shown among other probiotic products and strains known for their apoptotic effects on human colon cancer cells.

\section{Colorectal Cancer}

Evidence shows that intake of probiotics is an effective method for proper protection of the healthy gut microbiota and reducing the risk of colon cancer (18). Many in vitro and in vivo studies on this subject have been applied in animal models and human cancer cell lines. In contrast, there are few randomized placebocontrolled studies (RCTs) reporting that probiotics have an effect on the prevention and inhibition of intestinal carcinogenesis. Probiotics have intraluminal, systemic and direct effects on the intestinal mucosa (19). Among the mentioned intraluminal effects are competitive exclusion of pathogenic intestinal flora, alteration of intestinal microflora enzyme activity, reduction of carcinogenic secondary bile acids, binding of carcinogens and mutagens, and increased production of short-chain fatty acids. 
It is clearly supported by the available evidence that probiotics have a versatile immunomodulatory role in colorectal cancer (CRC), and particularly probiotics have ability to regulate intestinal inflammation, which is considered a major risk factor for CRC. Probiotics may show their benefits in this area, not only by preventing CRC, but also by improving side effects in patients undergoing colorectal surgery and being treated for CRC (17). A few of the randomized controlled studies have clearly demonstrated that the use of probiotics is an effective method that can be used in patients with CRC $(20,21)$. Studies have shown that, in patients undergoing abdominal surgery, the use of probiotics can prevent post-operative superficial incision surgical site infections and improve the integrity of the intestinal mucosal barrier. In addition, the use of probiotics improves the quality of life of patients, shortens the time spent in the hospital after surgery and the time needed for antibiotic administration.

Administration of probiotics as a mixture of one or more strains before surgery (preoperatively) in patients with CRC may reduce dysbiosis and similar bowel-related side effects (22). Gianotti et al. (22) showed that L. johnsonii (La1) modulated the gut microbiota by adhering to the colonic mucosa after its preoperative administration, by reducing pathogen concentration, and by reducing local immunity. The study also showed that Lal was more effective than another probiotic, B. longum (BB536).

Liu et al. (23) showed in two studies that administration of probiotics (L. plantarum, L. acidophilus, and B. longum) before colorectomy improved intestinal mucosal barrier integrity, decreased the rate of post-surgical infection and septicemia, shortened the duration of antibiotic treatment, inhibited the p38-MAPK signaling pathway, decreased serum serum level of zonulin, and also protected the liver barrier from metastasis (24). Zonulin is a protein synthesized by liver and intestinal cells, and when the regulation of this pathway is disrupted, autoimmune, inflammatory and neoplastic disorders may occur. Pala et al. (25) included 45,241 volunteers recruited from the The European Prospective Investigation into Cancer and Nutrition (EPIC) cohort. As a result of such a comprehensive study, it was reported that there was a decrease in the risk of CRC with yogurt consumption. In the study of Gao et al. (26), Lactobacillus reuteri was shown to suppress colon cancer due to inflammation by providing luminal histamine production, and it was observed that histamine-producing probiotic reduced the number of tumors in the colon and shrunk tumors. It is known that traditional methods used in cancer treatment such as chemotherapy and radiotherapy cause changes in the intestinal microbiota, and these methods can cause mucositis, bacteremia and especially diarrhea (17). Promising results were observed in studies that followed the use of probiotics for the prevention of mucositis in individuals with cancer. In studies in patients with CRC undergoing chemotherapy and radiotherapy, administration of a mixture of eight probiotics, including $L$. rhamnosus $G G$, significantly reduced the incidence of diarrhea. Prevention of CRC by probiotics depends on the type of microorganism (19). With this, there are also studies stating that viability in probiotics to be used is not one of the conditions sought for anticancer mechanisms. It is predicted that the opportunity to discover new strains with probiotic properties and anti-CRC activities will arise in the coming period with the understanding developed from advanced techniques and gut microbiome research (27).

\section{Gastric Cancer}

GC ranks fourth among the most common cancer types in the world and third among the main causes of death from cancer (28). The fifth most common type of malignant tumors is GC and surgical intervention is used as the main method for treatment. Studies in patients with GC show that early postoperative enteral nutrition (EN) may aid recovery. However, EN can also cause some complications. Diarrhea, the most common among them, causes fluid and electrolyte loss. The use of probiotics in patients with GC may reduce the incidence of diarrhea. With the administration of a combination of $\mathrm{EN}$ and probiotics, positive responses such as improved immune function and decreased inflammatory response can be seen in patients with GC in the postoperative period. A RCT by Zhao et al. (29) supports the effects of probiotic use in ameliorating the complications of EN. Considering the results, it appears that the combination of probiotics and fiber reduces the incidence of diarrhea, increases bowel motility and reduces bowel disorders in patients with GC in the postoperative period.

Most of the studies investigating the relationship between probiotics and GC are mainly directed at fighting Helicobacter pylori (H. Pylori) infection, which has properties such as disrupting the acid mucus barrier and colonizing the gastric epithelium (17). Positive inhibitory effects of probiotics including $B$. bifidum, $L$. acidophilus, L. rhamnosus, L. salivarius and several other probiotics to abolish $H$. pylori infection can be observed in animal models (30). Another study investigated the administration of kimchi, a Korean probiotic, in humans and mice with GC due to $H$. pylori (31). In the study, $H$. pylori-infected C57BL/6 mice were treated with anti-cancer kimchi (cpKimchi) mixed in water for 36 weeks, and standard kimchi and specially prepared kimchi were compared for their anti-inflammatory and anti-mutagenesis properties. Significant reduction in tumorigenesis in the H. pylori infected group were noted in those using cpKimchi. As a result, it is stated that cpKimchi administration provides significant changes in fecal microbiota and anti-cancer activities.

\section{Other Gastrointestinal Cancers}

Although less numerous than studies on CRC and GC, studies have also been conducted to show the relationship of probiotics to other types of GI cancer, such as esophageal, pancreatic, and liver cancers (17). In some previous studies, it is supported that probiotics exert their effects on pancreatic cancer through many different mechanisms by controlling risk factors such as, diabetes, pancreatic necrosis, inflammation and obesity. Among all cancers, liver cancer is less common (7). Its origin is liver cells, which are often referred to as hepatocytes. For this reason, a significant portion of liver cancers are called hepatocellular cancer (HCC). There are limited studies investigating the effects of probiotics on liver cancer. However, it is supported by studies that probiotics reduce hepatocyte damage, inflammation and proinflammatory 
cytokines, while increasing antioxidant activity. In these ways, it can be determined that probiotics have a role in preventing the formation of liver cancer. In another study by Li et al. (32), in which probiotics were reported to inhibit HCC progression in mice, the results of feeding tumor-injected mice with a probiotic mixture were compared with the control group. As a result, it is suggested that probiotics can alter the composition of the microbiota and reduce the size of liver tumors. In addition, it has been shown in the study that angiogenic factors can also be regulated by probiotic administration.

\section{Bladder Cancer}

Although Bacillus calmette guerin (BCG) is the current gold standard immunotherapy for bladder cancer, the rate of responders is $50-70 \%$ and it has side effects (33). In a study, it was investigated whether Lactobacillus rhamnosus GG (LGG) could be as effective in bladder cancer as BCG. In this study, it was observed that LGG treatment greatly $(p=0.006)$ increased the treatment response in mice, restored XCL1 levels in bladders, and recruited large numbers of macrophages and neutrophils to the tumor site. When cure rates of LGG and BCG immunotherapies were compared with cure rate in untreated mice, cure rates was $20 \%$ in untreated mice, $89 \%$ in LGG group, and 77\% in BCG group, indicating that LGG may have the potential to replace BCG immunotherapy in the treatment of bladder cancer. Another study indicated that probiotics increased the activity of dendritic cells, which had a significant effect on immune manipulation by causing the mobilization of natural killer cells (34). It suggests that it may be possible to minimize the risk of bladder cancer with probiotic supplements.

\section{Prostat Cancer}

Tumor necrosis factor-associated apoptosis-inducing ligand (TNFAIL) induces apoptosis in malignant tumor cells as an endogenous cytokine (35). In a study, it was shown for the first time that Lactobacillus started TNFAIL production in human peripheral blood mononuclear cells (PBMC) and induced TNFAIL production on the surface of PBMC and in culture medium. Treatment with Lactobacillus facilitated the natural killer activity of PBMC against prostate cancer. According to the results of the study, Lactobacillus facilitated the natural killer activity by producing TNFAIL and there was a possibility that a new TNFAIL-based treatment strategy might emerge against malignant tumors.

\section{Skin Cancer}

A study examined the prophylactic effect of probiotics and their metabolites against skin cancer (36). Hairless mice were orally administered lipoteichoic acids obtained from Lactobacillus rhamnosus $G G$. According to the results of the study, it was observed that the $\mathrm{T}$ cells of the treated subjects produced more interferon- $\gamma, \mathrm{TH}$ and CTL cells. In addition, a delay in tumor appearance was also observed. In addition, the immuneenhancing effect of lipoteichoic acids was emphasized. In another study, the effects of kefir on skin cancer were examined and a significant decrease was observed in intracellular reactive oxygen species, while suppressing the morphological changes caused by UVC irradiation (37). It was also observed that it suppressed apoptosis, prevented the formation of thymine dimer, and did not cause HMV-1 cell death caused by UVC irradiation.

\section{Head and Neck Cancer}

One study examined the effects of Lactobacillus acidophilus on tongue cancer (38). Cancer cells were incubated with probiotics for forty-eight hours, and as a result, it was observed that the proliferation of cancerous cells was greatly inhibited. It is thought that free radicals and $\mathrm{Ca} 2+$ increase in cells may cause this.

\section{Breast Cancer}

Surfactin produced from the Bacillus subtilis probiotic has been found to have an anticancer effect against breast cancer cells (39). It has been stated that this effect of surfactin is dose dependent and it inhibits cell growth by approximately $10 \mu \mathrm{g} / \mathrm{mL}$ in 24 hours. Another study examined the effect of Lactobacillus casei shirota on breast cancer in Japanese women (40). Regular consumption of Lactobacillus and isoflavones since puberty has been shown to be inversely proportional to the incidence of breast cancer. Although the interaction of Lactobacillus with isoflavones is not statistically significant, it is thought to be a biological interaction. In a study on mice, the effect of orally ingestion of Lactobacillus acidophilus on mammary tumors was investigated (41). According to the results of the study, it was observed that the treated group had more interleukin 12 production and less transforming growth factor production. A decrease in tumor growth rate was also observed. Another experiment on mice examined the immunomodulatory effects of Lactobacillus acidophilus (42). Administration of probiotics together with a chemotherapeutic agent (cyclophosphamide) for 15 days significantly regressed the tumor, increased lymphocyte proliferation and caused a change in cytokine expression pattern.

\section{Leukemia}

In a study, the apoptotic effect of kefir grain product (Lactobacillus) on multidrug resistant (MDR) leukemia cells was investigated by probiotic fermentation technology (PFT) (43). PFT was shown to increase apoptosis in cancer cells in a dose-dependent manner. The obtained data showed that treatment of cancer cells with PFT caused a remarkable reduction in mitochondrial polarization compared with untreated cells. The results indicated that PFT might be a potential therapy for the treatment of MDR leukemia. Kefir consumption is recommended for those with adult lymphoblastic leukemia based on its pro-apoptotic effect (36). In addition, kefir consumption causes decreased cell proliferation and increased apoptosis in leukemia $(44,45)$. Chiu described bacterial soluble factors secreted by Lactobacillus casei rhamnosus which were shown to increase apoptosis of the human monocytic leukemia cell line (46).

A two-year-old child diagnosed as having leukemia and treated for it developed severe neutropenia and increased inflammation (47). Looking at the laboratory test results, Bifidobacterium breve was found. However, Bifidobacterium breve was not found when the child's food was examined. Bifidobacterium spp. sometimes 
cause serious diseases and infections. B. breve septicemia was also found in another neonate treated with probiotics (48). A case of $B$. breve sepsis who had acute B-cell lymphoblastic leukemia was also reported (49). Therefore, it is not recommended to use probiotics as therapeutics due to their invasiveness. It has also been thought that the gut microbiota may regulate host immunity and homeostasis (50). However, it has been stated that these positive effects are strain and/or species specific.

\section{Conclusion}

It is supported by studies that the microbiota, which is accepted as an organ on its own, has an important place in the diagnosis and treatment of diseases. In this context, probiotics continue to gain importance. Cancer is one of the diseases in which the mechanisms of action of probiotics are being investigated. There are many genetic and environmental causes that cause the formation of cancer, which is among the top causes of death in the world. In addition to the traditional methods used for cancer treatment, innovative research still continues. Although there are studies investigating the importance of probiotics in the diagnosis and treatment of cancer, their mechanism of action has not yet been fully explained. However, it is seen that most of the researches are for a limited number of cancer types, and more researches covering all cancer types are needed. While the strongest evidence for the anticancer effects of probiotics comes from animal studies, the evidence from human studies (epidemiology and experimental) appears to be still limited. Carefully designed human clinical trials to validate the wealth of experimental studies should be an important target for the future. In many studies, it is reported that the positive effects of probiotics vary greatly according to the type and strain of bacteria. In this direction, the effects of different probiotic strains on cancer formation and its mechanism should be determined, so that strains with positive effects should be identified. In addition, it should be observed whether the combination of probiotics with prebiotics or with each other is effective on cancer types. As a result, it is necessary to conduct many comprehensive and multidisciplinary studies to investigate the effects of probiotics on cancer types.

Peer-review: Externally peer reviewed.

Authorship Contributions

Concept: A.G.B., Design: D.Ş., H.N.B, A.G.B., Data Collection or Processing: D.Ş., H.N.B, Analysis or Interpretation: D.Ş., H.N.B, A.G.B., Literature Search: D.Ş., H.N.B, Writing: D.Ş., H.N.B, A.G.B.

Conflict of Interest: No conflict of interest was declared by the authors.

Financial Disclosure: The authors declared that this study received no financial support.

\section{References}

1. Pandey KR, Naik SR, Vakil BV. Probiotics, prebiotics and synbioticsa review. J Food Sci Technol 2015;52:7577-87.
2. Aureli P, Capurso L, Castellazzi AM, Clerici M, Giovannini M, Morelli L, et al. Probiotics and health: an evidence-based review. Pharmacol Res 2011;63:366-76.

3. Butel MJ. Probiotics, gut microbiota and health. Med Mal Infect 2014;44:1-8.

4. Williams NT. Probiotics. Am J Health Syst Pharm 2010;67:449-58.

5. Tripathi MK, Giri SK. Probiotic Functional Foods: Survival of Probiotics During Processing and Storage. Journal of Functional Foods 2014;9:225-41.

6. Baykara O. Current Modalities in Treatment of Cancer. Balıkesir Health Sciences Journal 2016;5:154-65.

7. Kahraman M, Karahan AG. Tumor Suppresor Effects of Probiotics. Türk Hij Den Biyol Derg 2018;75:421-42.

8. Tüfekçi Alphan ME. Hastalıklarda Beslenme Tedavisi. Hatiboğlu Yayınları; 2018.

9. Górska A, Przystupski D, Niemczura MJ, Kulbacka J. Probiotic Bacteria: A Promising Tool in Cancer Prevention and Therapy. Curr Microbiol 2019;76:939-49.

10. Chandel D, Sharma M, Chawla V, Sachdeva N, Shukla G. Isolation, characterization and identification of antigenotoxic and anticancerous indigenous probiotics and their prophylactic potential in experimental colon carcinogenesis. Sci Rep 2019;9:14769.

11. Liong MT. Probiotics: a critical review of their potential role as antihypertensives, immune modulators, hypocholesterolemics, and perimenopausal treatments. Nutr Rev 2007;65:316-28.

12. Valeriano VD, Parungao-Balolong MM, Kang DK. In Vitro Evaluation of the Mucin-Adhesion Ability and Probiotic Potential of Lactobacillus mucosae LM1. Journal of Applied Microbiology 2014; 117:485-97.

13. Sanders ME, Akkermans LM, Haller D, Hammerman C, Heimbach J, Hörmannsperger G, et al. Safety assessment of probiotics for human use. Gut Microbes 2010;1:164-85.

14. Haukioja A. Probiotics and oral health. Eur J Dent 2010;4:348-55.

15. Serban DE. Gastrointestinal cancers: influence of gut microbiota, probiotics and prebiotics. Cancer Lett 2014;345:258-70.

16. Javanmard A, Ashtari S, Sabet B, Davoodi SH, Rostami-Nejad M, Esmaeil Akbari M, et al. Probiotics and their role in gastrointestinal cancers prevention and treatment; an overview. Gastroenterol Hepatol Bed Bench 2018;11:284-95.

17. Orlando A, Refolo MG, Messa C, Amati L, Lavermicocca P, Guerra $\mathrm{V}$, et al. Antiproliferative and proapoptotic effects of viable or heatkilled Lactobacillus paracasei IMPC2.1 and Lactobacillus rhamnosus GG in HGC-27 gastric and DLD-1 colon cell lines. Nutr Cancer 2012;64:1103-11.

18. So SS, Wan ML, El-Nezami H. Probiotics-mediated suppression of cancer. Curr Opin Oncol 2017;29:62-72.

19. Chong ES. A potential role of probiotics in colorectal cancer prevention: review of possible mechanisms of action. World J Microbiol Biotechnol 2014;30:351-74.

20. Kotzampassi K, Stavrou G, Damoraki G, Georgitsi M, Basdanis G, Tsaousi G, et al. A Four-Probiotics Regimen Reduces Postoperative Complications After Colorectal Surgery: A Randomized, DoubleBlind, Placebo-Controlled Study. World J Surg 2015;39:2776-83. 
21. Aisu N, Tanimura SHU, Yamashita Y, Yamashita K, Maki K, Yoshida, et al. Impact of Perioperative Probiotic Treatment For Surgical Site Infections in Patients with Colorectal Cancer. Experimental and Therapeutic Medicine 2015;10:966-72.

22. Gianotti L, Morelli L, Galbiati F, Rocchetti S, Coppola S, Beneduce A, et al. A randomized double-blind trial on perioperative administration of probiotics in colorectal cancer patients. World J Gastroenterol 2010;16:167-75.

23. Liu ZH, Huang MJ, Zhang XW, Wang L, Huang NQ, Peng H, et al. The Effects of Perioperative Probiotic Treatment on Serum Zonulin Concentration and Subsequent Postoperative Infectious Complications After Colorectal Cancer Surgery: A Double-Center and Double-Blind Randomized Clinical Trial. The American Journal Of Clinical Nutrition 2012;97:117-26.

24. Liu Z, Li C, Huang M, Tong C, Zhang X, Wang L, et al. Positive Regulatory Effects of Perioperative Probiotic Treatment on Postoperative Liver Complications After Colorectal Liver Metastases Surgery: A Double-Center and Double-Blind Randomized Clinical Trial. BMC Gastroenterol 2015;15:34.

25. Pala V, Sieri S, Berrino F, Vineis P, Sacerdote C, Palli D, et al. Yogurt consumption and risk of colorectal cancer in the Italian European prospective investigation into cancer and nutrition cohort. Int J Cancer 2011;129:2712-9.

26. Gao C, Ganesh BP, Shi Z, Shah RR, Fultz R, Major A, et al. Gut Microbe-Mediated Suppression of Inflammation-Associated Colon Carcinogenesis by Luminal Histamine Production. Am J Pathol 2017;187:2323-36.

27. Ambalam P, Raman M, Purama RK, Doble M. Probiotics, prebiotics and colorectal cancer prevention. Best Pract Res Clin Gastroenterol 2016;30:119-31.

28. Xie H, Lu Q, Wang H, Zhu X, Guan Z. Effects of probiotics combined with enteral nutrition on immune function and inflammatory response in postoperative patients with gastric cancer. $\mathrm{J}$ BUON 2018;23:678-83.

29. Zhao R, Wang Y, Huang Y, Cui Y, Xia L, Rao Z, et al. Effects of Fiber and Probiotics on Diarrhea Associated with Enteral Nutrition in Gastric Cancer Patients: A Prospective Randomized and Controlled Trial. Medicine 2017;96:e8418.

30. Zhu XY, Liu F. Probiotics as an adjuvant treatment in Helicobacter pylori eradication therapy. J Dig Dis 2017;18:195-202.

31. Han YM, Park JM, Lee D, Oh JY, Hahm KB. Korean Probiotic Kimchi Prevented Helicobacter pylori-Associated Gastric Cancer in Mice and Human. The FASEB Journal 2017;31:1067-71.

32. Li J, Sung CY, Lee N, Ni Y, Pihlajamäki J, Panagiotou G, et al. Probiotics modulated gut microbiota suppresses hepatocellular carcinoma growth in mice. Proc Natl Acad Sci U S A 2016;113:E130615.

33. Seow SW, Cai S, Rahmat JN, Bay BH, Lee YK, Chan YH, et al. Lactobacillus rhamnosus GG induces tumor regression in mice bearing orthotopic bladder tumors. Cancer Sci 2010;101:751-8.

34. Feyisetan O, Tracey C, Hellawell GO. Probiotics, dendritic cells and bladder cancer. BJU Int 2012;109:1594-7.

35. Horinaka M, Yoshida T, Kishi A, Akatani K, Yasuda T, Kouhara J, et al. Lactobacillus strains induce TRAIL production and facilitate natural killer activity against cancer cells. FEBS Lett 2010;584:57782.
36. Weill FS, Cela EM, Paz ML, Ferrari A, Leoni J, González Maglio DH. Lipoteichoic acid from Lactobacillus rhamnosus GG as an oral photoprotective agent against UV-induced carcinogenesis. Br J Nutr 2013;109:457-66.

37. Patel S, Goyal A. Evolving Roles of Probiotics in Cancer Prophylaxis and Therapy. Probiotics Antimicrob Proteins 2013;5:59-67.

38. Shi X, Chen J, Che T, Bai D, He X. [A study on human tongue cancer cells' proliferation affected by Lactobacillus acidophilus]. Hua Xi Kou Qiang Yi Xue Za Zhi 2012;30:87-92.

39. Lee JH, Nam SH, Seo WT, Yun HD, Hong SY, Kim MK, et al. The Production of Surfactin During the Fermentation of cheonggukjang by Potential Probiotic Bacillus subtilis CSY191 and the Resultant Growth Suppression of MCF-7 Human Breast Cancer Cells. Food Chemistry 2012;131:1347-54.

40. Toi M, Hirota S, Tomotaki A, Sato N, Hozumi Y, Anan K, et al. Probiotic Beverage with Soy Isoflavone Consumption for Breast Cancer Prevention: A Case-control Study. Current Nutrition\&Food Science 2013;9:194-200.

41. Yazdi MH, Soltan Dallal MM, Hassan ZM, Holakuyee M, Agha Amiri S, Abolhassani M, et al. Oral administration of Lactobacillus acidophilus induces IL-12 production in spleen cell culture of BALB/c mice bearing transplanted breast tumour. Br J Nutr 2010;104:22732.

42. Maroof H, Hassan ZM, Mobarez AM, Mohamadabadi MA. Lactobacillus acidophilus could modulate the immune response against breast cancer in murine model. J Clin Immunol 2012;32:13539.

43. Ghoneum M, Gimzewski J. Apoptotic effect of a novel kefir product, PFT, on multidrug-resistant myeloid leukemia cells via a holepiercing mechanism. Int J Oncol 2014;44:830-7.

44. Maalouf K, Baydoun E, Rizk S. Kefir induces cell-cycle arrest and apoptosis in HTLV-1-negative malignant T-lymphocytes. Cancer Manag Res 2011;3:39-47.

45. Jalali F, Sharifi M, Salehi R. Kefir induces apoptosis and inhibits cell proliferation in human acute erythroleukemia. Med Oncol 2016;33:7.

46. Chiu YH, Hsieh YJ, Liao KW, Peng KC. Preferential promotion of apoptosis of monocytes by Lactobacillus casei rhamnosus soluble factors. Clin Nutr 2010;29:131-40.

47. Bottacini F, Ventura M, van Sinderen D, O'Connell Motherway M. Diversity, ecology and intestinal function of bifidobacteria. Microb Cell Fact 2014;13(Suppl 1):S4.

48. Ohishi A, Takahashi S, Ito Y, Ohishi Y, Tsukamoto K, Nanba Y, et al. Bifidobacterium septicemia associated with postoperative probiotic therapy in a neonate with omphalocele. J Pediatr 2010;156:679-81.

49. Redman MG, Ward EJ, Phillips RS. The efficacy and safety of probiotics in people with cancer: a systematic review. Ann Oncol 2014;25:1919-29.

50. Bindels LB, Beck R, Schakman O, Martin JC, De Backer F, Sohet FM, et al. Restoring Specific Lactobacilli Levels Decreases Inflammation and Muscle Atrophy Markers in an Acute Leukemia Mouse Model. PloS One 2012;7:e37971. 